\title{
Metaphors of nature and organicism in the epistemology of music: A "biosemiotic" introduction to the analysis of Jean Sibelius' symphonic thought
}

\author{
Eero Tarasti \\ Department of Musicology, University of Helsinki, \\ Vironkatu 1, 00014 Helsinki, Finland \\ e-mail: eero.tarasti@cc.helsinki.fi
}

\begin{abstract}
Metaphors of nature and organism play a central role in the epistemes of the Western culture and arts. The entire project of the 'modern' meant a separation of man from the cosmos and its laws. Signs and symbols are thought to be arbitrary and conventional social constructions. However, there are many returns to iconic imitations of nature and biological principles also in such an esoteric art as music. One of the highest aesthetic categories in Western art music is the so-called 'organic growth' which particularly manifests in symphony. The concepts of 'organic/inorganic' can be used as analytic terms, whereby one might even compare such composers as Jean Sibelius and Gustav Mahler. Music is said to be 'organic' when (1) its theme actors live in their proper Umwelt (or isotopy); (2) all music material stems from the same themes (it is innerly iconic); (3) all musical events follow each other coherently (inner indexicality or the principle of Growth); (4) music strives for some goal (temporality). Moreover the Uexküll idea of a particular Ich-Ton of every organism can be turned back to music. Hence we can say that every musical piece is like an 'organism' which has its Ich-Ton determining which signs it accepts and how it acts in the musical environment of its own and formed by other musical works.
\end{abstract}

\section{On the musically "organic"}

A crucial part of the aesthetics of Western art music deals with the concepts of the organic and organicism. In a still broader context, 
music is connected to the episteme of "nature". According to Claude Lévi-Strauss, by music we become conscious of the physiological roots of our being. In learned music, a special "pastoral" style was developed to portray nature. For example, many of the so-called topics of the classical style relate to nature and the outdoor life, such as the horn signals in Weber and at the opening of Beethoven's Les adieux. When Adorno said that "Sibelius' music is all Nature" (Es ist alles Natur), this statement referred to many things, but for him it was overall a negative aesthetic category in the musico-social situation in 1937. Closer inspection shows, however, that Jean Sibelius' work ranks alongside the "Nature music" of Beethoven's Pastoral Symphony and the overture to Mendelssohn's A Midsummer Night's Dream. The inconsistency in Adorno's thinking was that, when Sibelius evoked nature it was doomed immediately, but if Mahler did it, then it represented the progressive Hegelian Weltlauf.

Nature appears in so many ways in the aesthetics of Western art music that only Arthur Lovejoy, in his classic Nature as Aesthetic Norm (1948), has attempted to list them all. Nature can mean human nature, the cosmic order, imitation of nature, truthfulness, objective beauty, simplicity, symmetry, balance, the primacy of emotion, spontaneity, naivety, primitivism, irregularity, avoidance of symmetry, the expression of artist's voice, the fullness of human life, the savage, the fecundity, evolution, and so on. All of these categories obtain in music.

Along with the development of the idea of absolute music which meant instrumental music - there emerged the idea of the symphony and symphonism. This notion was in turn intimately related to the idea of organic growth. This aesthetic norm took hold, becoming an influential value in the entire tradition of symphonic music. In some countries, such as Finland, to write a symphony is still considered the high-mark of a career, whereas in France people shrug their shoulders and remark, "Symphonie, c'est lourd, c'est nordique". As is known, Debussy once left a concert hall in the middle of a Beethoven symphony, complaining "Oh no, now he starts to develop".

According to Ernst Kurth there were two important lines of development in the history of Western art music. One was the periodic formal principle, based on the lied and the march and developed by Viennese classicism. It is characterized by clear-cut two-, four-, and eight-bar units, out of which more expansive musical forms could be composed. The other principle was linear art, independent of any strict measures and bar lines, which started with Palestrina's polyphony and 
culminated in J. S. Bach's melodies, an example being the freely undulating line of the Chromatic Fantasy. These two principles were the basic forces of musical formation. In addition, for Kurth music was kinetic energy. The aural, manifest form (signifier) of music was not essential; music only appeared by means of or was represented by it. Thus, all of music approaches the status of "nature" if one interprets the latter in a Bergsonian way as élan vital, or living energy. For Kurth music was "organic" when it followed a free motor impulse. Quadrangular, periodic rhythm was for him something artificial, a kind of "cultural" filter overlaid upon nature, even though it was based on corporeality in the sense of singing and marching.

At approximately the same time as Kurth, another music theoretician in the German field, Heinrich Schenker, developed his own conception of tonal music, which was also based on "nature". Nature was for Schenker the triad, produced by the natural overtone series, which he called the "chord of nature" (Urklang), whose intervals were filled by a primal melodic line plus a bass, together forming the Ursatz. Prolongation of the latter by means of artistic improvisation produced the only "good" music. Good music — that is, the only music worth analyzing and listening to - was of course tonal music and particularly German tonal music. Schenker drew his concept of organicism from Goethe and the latter's doctrine of the metamorphosis of plants.

Kurth and Schenker represent two different views of organicism in music. According to Kurth, organicity or "kinetic energy" arises primarily in the ebb and flow of the linear, horizontal movement of music, or in semiotic language, in its syntagmatic structure. By contrast, for Schenker the organic appears in the vertical movement from a deep structure towards the surface, from Hintergrund to Vordergrund, that is to say, in music's paradigmatic structure. From the syntagmatic perspective, the organic nature of music obtains by a certain arabesque movement. L'art nouveau, for instance, would be an ideally "organic" style period, with its twining arabesques in leaf-like shapes. From the paradigmatic view, organicism is seen as the inner growth and unfolding of music. Stefan Kostka, in his Materials and Techniques of Twentieth-Century Music, defines what the organic is in music, as opposed to the inorganic. In a sub-chapter called "Nonorganic approaches to musical form", he writes the following:

A traditional painting depicts something, and if the painting is a good one, every part of the canvas contributes to the effectiveness of the visual message 
that the artist is trying to convey. In traditional literature every passage has its purpose - fleshing out a character, setting the mood, developing the plot, and so on. The same is generally true of music in the European tradition: the composition is considered to be greater than the sum of its parts, a work of art in which each passage has a function that is vital to the overall plan of a work. Think of any tonal work that you know well, and imagine what it would be like if its parts, themes, transitions and so forth were randomly rearranged. It might be interesting to see how it would turn out, but the piece would almost certainly not be as effective as a whole. (Kostka 1999: 152-153)

Kostka goes on to emphasize that twentieth-century music evidenced a widespread reaction against the traditional organic view, that is to say, against the idea of a composition as a teleological process. He singles out the so-called "moment" form of Stockhausen as the antithesis of organicity.

In a broader sense, however, the organicism of music can be connected with the general problem of the arbitrary, conventional articulation of a sign system versus the iconic or indexical articulation of same: all grammars, including musical ones, are in Saussurean theory arbitrary and constructed, based on a set of particular rules. These rules can further be made explicit and thereby artificially generate music endlessly, according to the model, or langue.

Contrary to this approach - which exemplifies the idea of nonorganic form - is the view of music as a design or Gestalt, terms used by the Canadian composer and music semiotician, David Lidov. Grammar, as a set of static rules, can of course never be organic. Only can design or gestalt be related to something living. In support of this view, we can note that reformers and inventors of musical grammars, such as Schoenberg, rarely number among "organic"-sounding composers. Nevertheless, in some cases even music written according to serial techniques can sound "organic", as do symphonies by Einojuhani Rautavaara.

This leads us to ask, At what point do we experience music as being organic? Is it the case that organicity, when experienced consciously, no longer seems as organic as it did before? In other words, is the organic an unconscious category, such that we should return to Rudolph Réti's ideas on the thematic process? In some cases it seems that organicity is the consequence of a certain activity of the musical enunciator, whether composer or interpreter. If too much deliberation goes into the composition, then the resulting music is no longer organic. Only when composition takes place in a trance or under inspiration is the result organic. Such a case would involve a special 
dialogical relationship between the utterance and the act of uttering, between the text and its producer.

Yet even this definition does not help us to clarify what "organic" means as a quality of a musical text. Why is one composition organic and another one not? One explanation is that all mechanical repetition and potpourri-like formations are inorganic. This idea is advanced by Boris Asafiev in his intonation theory. As late as in Beethoven's symphonies "a composition became an organically and psychologically motivated whole, which unfolds as growth and development" (Asafiev 1977, vol. 2: 489). As a an example Asafiev points to the overture to Wagner's Die Meistersinger. It is a hidden symphony, whose parts - sonata allegro, andante, scherzo, and finale - have been blended together in such a way as to follow each other logically. They occur, one after the other, as various phases of a cycle, as a single line of development (Asafiev 1977, vol. 2: 490). Asafiev also calls such an organic form "dialectic".

If such a fusion is to be taken as particularly "organic", then it is exemplified by such pieces as Liszt's B-minor Sonata, Schubert's Wanderer Fantasy, Sibelius' Seventh Symphony, as well as the blending together of the first movement and scherzo in the latter's Fifth Symphony. Reminiscent of Asafiev's view is Carl Dahlhaus' interpretation of Beethoven's symphonic form, when he insists that musical form is not like a scheme that can simply be filled with individual themes (Dahlhaus 1985: 369). Beethoven did not compose "in" form but "with" form. He may, for example, shift transitional material or aspects of the main theme into a subordinate theme. The difference between Schubert and Beethoven is thus clear. In Schubert the form is associative, potpourri-like, but in Beethoven it is "developing variation" (which term Dahlhaus borrows from Schoenberg): the idea of connecting certain motivic passages to each other, is experienced by the listener as a musical logic and as a counterpart to mere association.

In semiotic terms, syntagmatic linearity alone is not sufficient neither inner iconic similarity nor mere inner indexicality. The musical form has to be experienced as somehow goal-directed, or in Kantian terms, als zweckmässig, otherwise the music is not organic. Asafiev, too, pays attention to the goal-directedness of music, distinguishing between two types of telos or finalities in the symphonic literature: either the cheerful and free fusion of the personality with the cosmos (Beethoven) or spiritual pain and isolation amidst the crowd, oblivion, and tragic destruction. For Asafiev, musical finality 
is achieved when some leading idea is revealed, which captures attention and out of which the growing waves of development emerge (Asafiev 1977, vol. 2: 483). This Asafievian ideal is almost literally realized in Sibelius. In the Fifth Symphony, for example, there is a struggle to the end between these two forms of finality, and the listener remains unaware of which solution the composer has chosen.

Thus, in order for music to be organic, it is not enough that there be motivic and thematic unity, i.e., that the music consist of more than fortuitous variation. Nor is it enough that these variations follow each other indexically and smoothly. Music has to progress towards some goal or telos; music must be directional. But is not all music as a temporal art directed towards something? Here we do not mean the primary temporality of music but temporality as "marked", as Robert Hatten (1994) might put it. In organic music, musical time is organized towards a certain goal.

How is this goal created? That is, How does a listener know that the music has a goal and a direction? Leonard B. Meyer, in his Explaining Music (1978), presents a theory of melody that emphasizes well-formed melodic shapes. There are certain musico-cognitive archetypes, the breaking or deficient fulfilment of which causes the listener to remain waiting for the right solution, the correct design. (On this view, Lidov's theory of design would be sufficient to explain the organic nature of music.) For instance, if we hear at the beginning a "gap-fill" type of melody, then a telos of music is created by the unfilled gap, which may not be completed until the very end of the piece. This tension keeps the music in motion and produces the kinetic energy, the catalysing impulse. An example is the opening of Sibelius' Fifth Symphony, where a motive sounds that is incomplete in three respects. Firstly, this motive, which Tawaststjerna calls a "bucolic signal", is first rhythmically syncopated and heard in a strange 12/8 meter. Secondly, its verse structure is irregular, as Lorenz Luyken has remarked (1995: 42-43). Thirdly, it is based on an open fifth-fourth intervallic shape, which causes the listener to remain waiting for these gaps to be filled.

Harmonically the music hovers around the six-four chord of the Eflat major, a device similar to that which occurs at the beginning of Beethoven's Sonata Op. 31 No. 3. Beethoven lets the phrase cadence on the tonic rather soon, however, whereas Sibelius delays it until the very end of the symphony. There we also hear the fifths and fourths filled with a stepwise scale passage and leading tones: it is the great and relieving climax of the whole work, all the more since we have 
been oscillating between various tragic alternatives just before it arrives. The extremely restless and ambiguous theme on the Neapolitan chord ceases its wandering and is filled with a scale in E flat minor (which the sketches show to be one of the symphony's founding ideas). But even at the end of the symphony, where the tonic is confirmed with a cadence, rhythmic balance is still not reached, since not all of the cadential chords are on strong beats. There is a particular irony in this, a musical pun, the wish to show that this is not altogether too serious - a rare moment in Sibelius! The situation recalls what happens in a play when the clown returns and addresses the audience directly to recite the final words, or as in the closing morality segment of Mozart's Don Giovanni.

Music thus has its own telos, which sets energies in motion. They emerge from musical designs, gestalt qualities, of which we expect the completed form. According to Jan LaRue (1970), music has a special dimension of growth that binds all the other musical parameters together - this term in itself sounds rather "organic".

Can "organicism" arise from some other quality of the musical texture? For instance, Sibelius' music typically has fields that constitute the elements for the so-called "space dramaturgy" analyzed by Luyken (1995). Sibelius' music often seems to be driven into a kind of fenced-in area, from which there is no exit. The formation of such fields was already evident in early Sibelius, for instance, in En Saga (in Finnish: Satu), realized by means of a simple repetitive form. That is to say, the same melody or theme recurs until, by repetition, it loses its character as a musical subject that distinguishes itself from its surroundings, its musical Umwelt. The music itself becomes a subjectless environment. This is a particularly Sibelian way of deactorializing the music, so as to make it an impersonal and vegetative natural process in which no thinking or feeling subject can be seen. In the Fifth Symphony, such a field is formed by the chromatic lament motives in the first movement (score numbers $\mathrm{J}-\mathrm{M}$ ), which one hears for a very long time. (Such a situation is not far from Ligeti's field technique, which in turn is not the same as the "sonoristic" fields of the Polish school; see Mirka 1997.) But this predominantly "static" field arises from a continuous, micro-organic process. How does one enter into such a field, and how does one get out of it? In the Fifth Symphony the field is simply exhausted: one does not leave it by means of a musically determined "escape route", such as modulation (as occurs in the Second Symphony with the D-minor field in the Finale which leads into the parallel major). 
The question of the organic nature of music can also be interpreted as a question of the right method of analysis. One can imagine that methods based on musical "functions" would better take into account the organic quality than do tectonic, segmentational, mechanistic models (to which unfortunately the major part of music-semiotic analyses belong). The basic problem of organic music does not at all concern how music can be divided into smaller pieces but rather how the music coheres.

Boris Asafiev viewed music as consisting of three main functions: initium, motus, and terminus. In Greimassian semiotics these correspond to the so-called aspectual semes: inchoativity, durativity, and terminativity. In Claude Brémond's narratology, they parallel the three phases of storytelling: virtuality, passage/non-passage to action, achievement/inachievement. According to Asafiev the musical organic process always presupposes these three basic phases. Quite similar theories have been developed elsewhere. ${ }^{1}$

But there may be still other means by which music becomes organic. I have elsewhere introduced the biosemiotics and doctrine of Umwelt by Baltic biologist Jakob v. Uexküll, whose ideas have been provoking lively discussion among semioticians quite recently. What if we were to take his ideas seriously in music? As is known, his theory is based on the idea that every organism functions according to a preestablished "score" which determines the nature of its Umwelt. The organism connects to that world by two processes, Merken and Wirken. Every organism has its particular Ich-Ton which is determinant of its being and acting. We can see in this concept an analogy to music, and say that every theme, every musical motive, every intonation lives in its own, characteristic musical Umwelt. An organic composer takes into account expressly the relationship of a musical event to its musical environment. A good example of the relationship of a theme to its Umwelt would be the variations of the Andante theme in Beethoven's Fifth Symphony. There the main motive is continually shifted into new, interesting-sounding milieus; the listener pays more attention to these environments than to the theme itself.

In the classical tradition, melody and accompaniment are derived from the same material (as at the beginning of Schumann's $\mathrm{C}$ major Fantasy, where the accompaniment figure is the same as the

${ }^{1}$ Another, interesting "narratological" view of music can be found in the analysis manual of Ivanka Stoianova, used in her music courses at Paris University VIII. Stoianova takes her ideas mostly from her teachers in Moscow. 
descending theme in the upper register), in which case the organic nature of music lies in the interaction of musical event and its environment. By contrast, the postmodern style - early examples of which are Poulenc's Concerto for Two Pianos and even Stravinsky's neoclassicism - uses quotation techniques and avoids the aforementioned organic unity. The environment of the theme must be alienating. That is to say, if the context is tonal, then the citation has to distinguish itself as something dissonant. And if the context is atonal, the citation has to be distinguished by its tonality. In Sibelius' Fifth Symphony, even in the earlier version of 1915, there is a strangely dissonant, piercing variant of the so-called Neapolitan theme which is superimposed on the "Swan theme" - this is one of the rare futurist and fauvist moments in all of Sibelius' output. There the theme really appears as if it were in a wrong isotopy or musical Umwelt.

Are there other means by which music can become organic? Wilhelm Furtwängler in his writings paid attention to the biological foundation of all music. However, the use of the term "biology" in music is metaphorical and thus as ambiguous as the concept of "nature" when applied to any art form. To Furtwängler, the so-called "absolute" music of the classical period was much more than functional, casual music. Dahlhaus remarks that Vienna's musically rich and many-sided Umwelt enabled the emergence of the classical style. But Furtwängler believes that there was something else as well:

It is not only casual music bound with life [...] it is not directly connected with the ballet, play or drama, but can also well be so. What it touches, it changes. It gathers into it the fullness of the entire organic life and reflects it there like in a mirror. It creates from itself the extremely broad world of independent musical forms - lied form, fugue, sonata form are only its basic types. It is able to do so because it is enough for itself. It naturally corresponds to man's biological presuppositions. (Furtwängler 1951: 27)

Furtwängler then asks, What are these biological presuppositions? They are based on the alternation of tension and relaxation:

The ascending and descending movement of tension and release reflects the rhythm of life: as long as we breathe, one activity is at rest, the other one in motion. The state of rest is more original and primal [...]. One of the basic doctrines of modern biology is that in complicated bodily activities [...] the relaxation of tension has a decisive meaning. (Furtwängler 1951: 27) 
This is certainly an acceptable view. In my own theory of semiotics I speak of two basic modalities, 'being' and 'doing', derived from Greimas' model. But they also concern the definition of the organic in music (Tarasti 1994). What brings about being and doing in music? What gives us the impression that we either simply 'are' in music or that something is happening? These questions can be answered by observation of the temporal, spatial and actorial articulations in music. These articulations belong to the music of all cultures, not just to Western art music.

Furtwängler, however, relates 'being' (relaxation) and 'doing' (tension) strictly with tonality: "The state of rest in music in its full cogency is only produced by tonality. Only it is able to create an objectively existing state of rest (subjectively we can of course consider any personal impression as rest)". Furtwängler is thus bound to a certain musical ontology. The deepest level of music for him is always tonal, since it is based on the natural determining force given by the triad. It is the beginning and the end of everything.

Furtwängler's tonal ontology is a long-abandoned position, but in the context of our essay it has a certain meaning. Even some semiotically oriented scholars base their theories on a "biological" ontology, though without joining it any longer to tonality as a kind of ahistoric, universal principle. Ivanka Stoianova, for instance, thinks that musical form has two aspects: processual and architectonic. The processual aspect refers to musical enunciation, and the architectonic evokes the musical utterance as a ready-made text, as an art-work outside time. Thus we get two musical counterforces: the kinetic aspect, which is based on motion, change, process; and a static aspect, which is based on immobility, stability and architectonics. Musical form as a process, as aural manifestation, and the presence of an aural architecture are two sides of the same artistic activity.

Architectonic form - the external mould as described by Réti and Kandinsky — seems to be an effort to immobilize the stream of music. All musical style periods, from the classical to the romantic to the avant-garde, include such an immobilizing effect, which stems from architectonic form. The means of stopping the musical stream consist of hierarchic, historically determined formal schemes, whereas processuality appears in transformations and emergent contrasts, such as developing variation. For Stoianova, the 'being' of music is not precisely as it is for Furtwängler. It is not an ontological or teleological end-state of music toward which everything strives, but is rather the stopping of "normal", and hence, "biological", musical time. 
In this sense, generative models are epistemologically contradictory. The idea of a surface that is gradually generated from a deep structure is based on hierarchies, and thus on something static and architectonic, hence something which stops the musical movement. This has as its consequence the static, atemporal character and artificiality of generative analyses. They are mechanistic elucidations of musical grammars using hierarchic axiomatic rules. But at the same time, the idea of a generative course contains the thought of a process, in which the immanent is in the end made manifest. The generative course thus refers to a basic semiotic force of the whole universe: the movement from content to expression. Whether Greimas' generative course or Chomskian schemes, generative models can make explicit the "organic" course of processes of meaning, but at the same time they contain an inorganic and architectonic aspect, which is a strange principle when applied to phenomenal musical experience and belongs in this sense to the project of the "modern".

We can try to clarify further what the "organic" in music is, with a more detailed formal and style analysis. A good example is provided by Veijo Murtomäki's (1993) study of organic unity in Sibelius' symphonies. He confirms the importance of organic metaphors among all the representatives of the so-called "dynamic" form theory in German musicology. He mentions Kurth, Schenker, Halm and the continuation of their thought in Schoenberg and even Anton Webern. The musical views of the latter are permeated by the metaphor of a biological organism that develops from a single, initial idea. From it emerges the inner unity (zusammenhangen) of music. (It is interesting to note even here the contradictory tendency of these reformers of musical grammars and pioneers of the "modernist" project, who used models of thought inherited from romanticism. In addition, Schoenberg and Webern were certainly different persons as theoreticians and composers. How a serial piece can be organic remains in this context unanswered.) In any case, Murtomäki lists in his study five ways in which music can be organic, with special emphasis on how Stoianova's immobilizing forms - such as sonata, symphony, string quartet, and so on - become organic or processual by means of cyclic technique. For Murtomäki, organicity obtains when a composition with more than one movement is made to sound like a whole, and this in turn is the same as cyclicity. Cyclic procedures can be either external or internal; that is, they can either unify the materials or join parts together: (1) first, movements may be linked by similar thematic openings; (2) either thematic "germs" or cells are moved almost 
imperceptibly from one movement to another, or themes appear in an easily recognizable guise in the later movements; (3) a special motto or idée fixe may appear in every movement; (4) the principle may be one of family unity: the parts are connected with metamorphoses of the same theme; (5) the most sophisticated way is continuous variation, a method of metamorphosis in which new ideas result from a process of transformation.

The last-mentioned case is the most exciting one. When do we experience in music that some process "generates" or gives birth to another event? Put another way, when do we experience that some event $T$ is the consequence of a former event $P$ ? Does event $T$ serve as the telos of event $P$ ? What precisely does this mean? The finale of Sibelius' Second Symphony is doubtless a good illustration of the idea of a telos, given the way that it is attained only after much struggle. But we can also imagine a process during which the listener does not know what will follow. Only when the result of $T$ is heard after the process of $P$ does one realize. Yes, this is exactly what everything prior to it was working toward. In such a case, one cannot say that $T$ serves as a teleological goal of $P$, since it is perceived as such only after the fact.

How can we semiotically analyze and interpret such relationships? From a narratological perspective we can consider some event a subject and its goal to be the event, an object, that is searched for by the subject. At first the subject is disjuncted from the object, but then reaches or is conjuncted with it, taking it into possession. For instance, a theme in the dominant key "wants" to be united to the tonic. Yet this does not quite correspond to the truth, since the result of the metamorphosis can in fact be something which its preceding event is not aware of, so to say, or does not even "want". Only the musical superenunciator - the composer - knows that event $T$ is a logical, organic result of process $P$. Or rather, the subject $S$ is transformed into another subject $S_{1}$ or $Q$ or $X$, when the music steps, as it were, into "otherness", when it shifts to some kind of non-being via the process of becoming. What is involved, then, is an organic, abruptly contrasting shift from a subject $S$ to a subject $Q$. The subjects $S$ and $Q$ are felt to belong to the same musical Umwelt, in which we move from the Lebenswelt of subject $S$ to that of subject $Q$.

To end this section on the metaphor of the "organic" as a musictheoretical episteme, we can note that the same thing happens with it as with the notion of "nature", discussed above. As Lovejoy's analysis and our cases show, "nature" can mean almost anything, both order 
and disorder. In the same way, organic unity and growth can mean almost anything whatsoever. Why, then, do we examine a phenomenon about which we cannot only come to the same conclusion as did the first-year student mentioned by Umberto Eco, who modestly presented "a short comment on the universe"? It is because nature and organic growth have meant something to philosophers and to musical scholars, especially to those studying symphonic thought. They are notions loaded with strong ideological concepts, whose precise meaning can be obscure, but which have been and are still used when we speak about essential things in music. We cannot ignore these terms only because of the uncomfortable fact that their linguistic usage is not always logical and coherent. Next I shall ponder their relevance to Sibelius, particularly regarding his Fifth Symphony.

\section{Sibelius and the idea of the "organic"}

One could respond to the challenge posed by Adorno, by claiming that Sibelius' music is "organic" whereas Mahler's music is "inorganic". In that case, the terms organic/inorganic would be primarily analytic concepts, such that "organic" music would be based on the following conditions: (1) All the musical actors live in their proper Umwelt; in semiotic terms, the themes move in their proper isotopies. (2) All the musical material stems from the same source; that is to say, thematicity, in semiotic terms, would be innerly iconic. (3) All the musical events follow each other coherently; this is LaRue's principle of growth, or the inner indexicality of music. (4) The music strives for some goal; this has to do with temporality and the aspectual semes of beginning, continuing, and closing.

Sibelius' music can be experienced in many ways as "organic". First, many think that the category of Nature is present therein. As Lorenz Luyken has stated, Sibelius' music refers to the pastoral quality, in the manner of Beethoven, Mendelssohn, and Wagner. There is much evidence, on the part of both Finnish and non-Finnish scholars, that the poiesis and aesthesis of his music is connected to Finland's nature. When Leonard Bernstein introduces Sibelius' mixolydian mode in the Sixth Symphony to an audience of young listeners in New York, he says that it evokes the lonely forests of Finland. When music semiotician Jean-Jacques Nattiez visited Helsinki in April of 1979, he spontaneously started to whistle the 
opening motive of the Violin Concerto when looking at the frozen sea from the bridge of Seurasaari in Helsinki. But closeness to nature does not make music innerly, analytically "organic". It is only a category of reception.

What about the level of poiesis? Erik Tawaststjerna carefully studied the sketches of the Fifth Symphony and their elaboration. He connects the Fifth Symphony to Scriabin's ecstatic-mystical view of art and to the Russian composer's empathy with the cosmos. After quoting a poem by Scriabin, Tawaststjerna (1978: 18) says, "But it is not erroneous to think what appealed to Sibelius in Scriabin was precisely the 'cosmic' dimension of his music, which is related also to his efforts to break through the boundaries of tonality". This quotation has to be read in the light of our interpretation of the project of the "modern", insofar as it represents the detachment of man from "cosmos" and insofar as "organic" music means a return to this cosmic unity. For Scriabin it meant going to the extreme limits of tonality (albeit Prometheus closes with an F-sharp major tonic). But in Sibelius the "cosmic" style and rejection of the modernist project meant expressly the acceptance of tonality. The ecstatic E-flat major at the end of the Fifth Symphony is related to the finale of Musorgsky's Pictures at an Exhibition, which also cadences to a similar, waving, clock-like motive. From this we might infer that the organic style and the return to cosmic unity, in the philosophical sense advanced by Charles Taylor (1989) in his The Sources of the Self, is not always the same as the return to tonality. This engagement, this embrayage (Greimas' semiotic term), can also take place on levels of the musical text other than spatial ones.

Tawaststjerna's study in fact seems to prove Sibelius' organic symphonic logic is based upon composer's way of elaborating the material; it is clearly the category of poiesis. Tawaststjerna is moreover inclined to think that the organic quality of Sibelius' symphonies emerges as a result of a trance-like process guided by the unconscious inspiration of the composer. When discussing the creation of the Fifth Symphony he deals with many of the various ideas found in the sketches, which Sibelius used in his Fifth or Sixth Symphonies. He compares this process to a puzzle whose pieces are fragments of a mosaic "floor of the sky" (Tawaststjerna 1978: 61). In this phase the symphony still essentially appears as a paradigmatic table, and its elaboration is a completely rational, non-organic occupation. But then Tawaststjerna continues: 
In the case of Sibelius I am inclined to consider his creative work an interaction of inspirational and intellectual components. Their relationship continuously varies. Basically he was dependent on his inspiration. He had his 'wonderful' trances [...]. The shaping of the themes seems to have happened intuitively. (Tawaststjerna 1978: 65)

Nevertheless, if we think of our aforementioned criteria for organicity, one might state that on a paradigmatic level the organic trait stems from the inner similarity of the musical substance. Tawaststjerna reduces all the motives of the Fifth Symphony to two: the so-called step motive and the swing motive. But even this is not enough: the material has to be put into a syntagmatically coherent order. Only then can we experience music as organic.

Erkki Salmenhaara, another Finnish Sibelius specialist, has a similar view of Sibelius' organic techniques. Like Tawaststjerna, he stresses that organicity emerges in the mind of the composer, who using musical criteria chooses from an endless group of paradigms those which are meaningful regarding the intended musical shape. In his study on the symphonic poem Tapiola Salmenhaara quotes the British scholar Cecil Gray: "The thematic materials in Sibelius [...] seem to regenerate in a way which the biologists call cell division: they are split and broken into seven theme units, when every bar of the original organism is subjected to a development" (Salmenhaara 1970: 37). Therefore under the conventional formal outline of music there looms another shape which is dynamic, processual, or, in our terminology, "organic". 2 In the chapter on "Sibelius' Organic Principle of Variation", Salmenhaara starts to deal with the organic nature of the composer's logic: "By organic development it must be understood that various results of the development - different themes and motives are in an 'organic' connection with each other" (Salmenhaara 1970: 59). What is interesting here is Salmenhaara's term "results". Themes in organic music can be experienced as results of some process which is not the same as the telos, the Kantian Zweck. There are of course processes that from the beginning aim for a certain goal, but there are also processes whose result is not known in advance. For instance, the transition to the Finale of Beethoven's Fifth Symphony, the long pedal point on $\mathrm{G}$, leads finally to the theme of victory, which is something like a product of this process: we know to expect something, but are not sure exactly what. The same thing occurs with

${ }^{2}$ The differentiation between the static and the mobile recalls Ivanka Stoianova's distinction between architectonic and dynamic forms. 
the intermediate section of the Waldstein, which leads to the sunrise theme of the last movement. Sometimes the result of the process is quite amazing, as in Sibelius' Karelia music, where a long transition takes place before the theme bursts out: the national anthem of Finland. The result does not grow organically from the previous material but is a quotation justified by an extramusical program.

Salmenhaara also defines what is nonorganic music, one example being the variation sets of the classical style. In them the gestalt of the theme remains the same; it is just ornamented - think of Unser dummer Pöbel meint or Ah vous dirai-je Maman by Mozart. On the other hand, Salmenhaara emphasizes that in an organic variation what is crucial is not the goal of the process but the metamorphosis itself. "It is like a self-reflecting process: the main thing is not that the development form bridges among architectonic climaxes, but the aim is for continuous transformation, the constant turning of the motives into new shapes" (Salmenhaara 1970: 60-61). This latter comment is of great interest since it excludes telos from organicity: the organic transformation does not have a goal to strive for; rather, the variation becomes self-reflexive. What kind of phenomenal experience would this evoke? Doubtless a kind of static, slowly changing sound field. Has Salmenhaara unknowingly projected the Ligetian field technique onto Sibelius in order to see him as a representative of a certain avantgarde movement? If organicity were the same as Ligeti's field technique, that would place Sibelius within the panorama of the new music of the twentieth century. The listener easily experiences such fields as a kind of stasis, a limbo from which there is no exit. This situation undeniably occurs in Sibelius' Fifth Symphony, especially at score letters $\mathrm{J}$ and $\mathrm{K}$. The Allegro moderato section of $\mathrm{K}-\mathrm{P}$, and also the fluttering, Mendelssohnian figuration of the strings in the last movement, contain such self-reflexive organic transformation.

It is essential to this line of reasoning that we speak about music as shapes or Gestalts but not as grammar, recalling David Lidov's two principles of "grammar" and "design". There are composers, such as Arnold Schoenberg, who have concentrated on reforming musical grammars. Then there are composers whose main contribution is at the level of gestalt, who make innovations even when the grammar remains the same. Debussy, Stravinsky, Sibelius seem to belong to this line. Therefore Adorno could not appreciate them. His hyperrational music philosophy is definitely bound with the project of the "modern" in the aforementioned philosophical sense. Music is grammar, conventional, arbitrary, and it has to maintain this aura of artifi- 
ciality in order to be progressive. Music which functions via iconic shapes would mean a rejection of the critical distance and consciousness of the listener. Since over the course of time humankind has become disconnected from nature and cosmos, one must remain constantly aware of this primal negation and difference. The return to unity with the cosmos, with nature, would mean the return to a lawless and barbarous original state (the Germany of the 1930s is an example). It is always regression. The idea of organic music is precisely to return the listener to the cosmos, to natural principles which appear as the art of pre-linguistic gestalts. Organic music is prelinguistic, non-verbal, in the profound sense of the word. It is impossible to reduce Sibelius' music to the language-likeness of tropes or rhetorical figures.

There is, however, one difficulty in defining the organic, and it is clearly noticed by Salmenhaara when he says, "[...] organic transformation has one special feature which is difficult to analyze, namely, it is musical by nature. Precisely here we have the difference between the motivic techniques of Sibelius and Schoenberg. The music of the latter is theoretical and technical in nature rather than based on musical gestalts" (Salmenhaara 1970: 62). The twelve tones of a row can be manipulated in many ways which do not have a meaningcreating shape. Seen in this light, organic music is precisely music of design.

How, then, can we prove that music based on a complicated motivic technique is organic? Only a tiny part of all possible motivic transformations is really used. Only those motives which are musically meaningful are taken into account, and that is why the organic unity of these motives is also noticeable to the listener. The musical construction does not follow any external system - just purely musical logic.

Hence the term "organic" means the same as the "musically logical" which in turn means the "musically meaningful". So we have fallen to a circle. What does it mean for something to be "very musical"? Sometimes it means the rendering of the emotional content of music, or that the musical performance in some way touches or speaks to us. But if we say that a musical text is "musical", that reveals very little indeed. We cannot only look at the text, the score. We must consider the entire situation of musical communication, not only the utterance, but the utterer as well. Only the choice of the human "brain" or enunciator or composer can make any music organic. Thus, what is involved is a quality that is made manifest by 
the musical enunciator, in the dialogue between musical material and the persons who deal with it. Insofar as the musical mind intuitively filters and shapes musical materials into a certain gestalt quality, music becomes organic. Neither mere mathematical structure nor grammaticality suffice to make music organic. Although utterances may be "well-formed" or "grammatical", we do not necessarily experience them as organic. Principles said to stem from the brain of the enunciator have been studied by statistic-mathematical methods in Russia, which methods are derived from the so-called "law of Zipf". The latter says that, when all the notes or words of an art work are counted, they can be shown to follow a certain distribution along the "Zipf curve". Using this model, one can determine when a work is overwritten or underwritten, that is, when it has too many or too few notes. Works written by a great master in one breath, as it were, follow the Zipf law better than those written in episodically. Here the question of the organic is shifted from the textual level into a cognitive question: How does the enunciator pick those elements which on the textual level will become organic?

To begin to answer this question, one might try to apply Uexküll's biosemiotic theory to music. As discussed above, each organism has its own Ich-Ton, which determines the kinds of messages it receives from the outside, from the Umwelt that surrounds it. If this concept were applied to music, it would mean that every composition is a kind of "model" of a living organism, the latter understood in a certain "as if" sense. The life of such an organism, its 'being' and 'doing', is guided by its view of itself, which helps the organism to choose according to its "inner" score those signs which it sends and receives. If a musical organism consists of motives, these motives constitute kinds of "cells" that communicate with each other, as happens in living organisms. This communication is completely determined by the inner organisation of the organism, its Ich-Ton.

Music is the symbolic description of this process. The musical organism that emerges from the brain of the composer somehow takes shape from a certain basic idea or isotopy, what Sibelius called an "atmosphere", which determines which motives are accepted into this inner process and which ones are rejected. When we observe this microlevel of musical "cells" the life of the musical organism, we can follow what some cell or motive or "actor" is doing and how it does so, that is, how it influences other cells. Sometimes the "act" of a motive at first goes unnoticed, becoming influential only later. Sometimes the composer decides upon the Ich-Ton of the work as 
early as in the opening bars. For instance, the core motive of Sibelius' Fourth Symphony sounds at the very start of the work. In the same way, the "bucolic" horn signal at the opening of the Fifth Symphony is a "cell" which, in order to become a complete gestalt, needs to have its interval filled, and this is heard only at the end of the symphony. So we can say that, in music as in living organisms, one cell "calls out" for another. Precisely this type of inner process in a work makes it organic.

Organicity or organicism is therefore dependent on the enunciator's - i.e., the composer's - consciousness. In organic music, this consciousness in turn follows the biosemiotic principle by which motives communicate with each other according to a certain "inner" score. One may presume that the inner score is different in each work. But one may also claim that in certain respects it is always the same, as Schenker's, Kurth's, and Asafiev's theories assert. Nevertheless, the idea of an organic composition cannot be limited to a single, universal principle. For nature's scope of variation is unlimited, and thus always capable of producing new types of organisms. Basically, however, the organism always decides upon its own Umwelt or relationship to external reality. It is the organism that determines which signals, style influences, motivic borrowings, and so on that it accepts from the style of the time, from other composers, and even from itself. An instance of the latter occurs in Sibelius' moving materials from the Sixth Symphony to the Fifth. That is to say, the Ich-Ton of the Fifth Symphony, its "inner score", allowed certain signs to be shifted into its own "cells", while rejecting others.

We can now return to the thesis presented above, namely, that Sibelius' music is organic and Mahler's is not. The Ich-Ton of Sibelius' symphonies determines precisely which musical cells are accepted and adopted into the inner network of musical communication, that is to say, into the "community" of its musical actors. In contrast, Mahler chooses very heterogenous elements; his music's IchTon is far more fragmentary than that of Sibelius - it is contradictory and "modern". Mahler's symphonies encompass everything, but do so without the aforementioned selection criteria of the Umwelt. His musical actors do not communicate with each other as intensively or as intimately as they do in Sibelius. Rather, Mahler's work is ruled by "unit forms", by topics and musical cells articulated by social conventions. His music adapts itself more to structures of communication than to those of signification. 
One of the best-known recent interpretations of Sibelius' Fifth Symphony is the one by James Hepokoski (1993). His central concept for explaining formal issues in Sibelius is the so-called rotation principle. Hepokoski denies the relevance of traditional Formenlehre for Sibelius, since according to the composer his musical form grew from the inside out, as he said often to his secretary Santeri Levas (see Hepokoski 1993: 22). Hepokoski says that it is typical of Sibelius to use repetition to erase, so to speak, the linear time of a work; he does so by letting certain elements, motives, and entire sections recur cyclically again and again. Hepokoski thinks this phenomenon stems from the Finnish Kalevala recitation, as shown in the song Illalle (Op. 17 No. 6). There a figure of 11 notes is repeated 16 times! Hepokoski notices that the rotation idea occurs not only Russian but also in Austrian-German music, such as that of Schubert and Bruckner. In Sibelius, however, the rotation is a process rather than an architectonic scheme or mould. In this sense, such rotation suits well as an example of organic music. In Hepokoski's view, the rotational process starts with some musical statement that serves as the point of reference for later statements. The statement can be extensive at first hearing, containing various themes, motives, and figures which can even differ one from the other. It returns later, when it has been transformed a little, and it can return many times, such that it is heard each time more intensively.

In Hepokoski's theory the rotation principle in Sibelius is connected with the idea of a telos, that is, with the final climax of a piece as the goal of the musical process. Together, these two principles rotation and telos - help explain the form of entire works, such as the Fifth Symphony. From the perspective of organicism, Hepokoski's notion of rotation provides the inner iconicity of a work, and telos serves as the extreme point of maturation of the work, which, so to say, pulls earlier rotations toward itself, causing them to grow and transform. From the beginning, inner processes among musical signs aim for the climax. This view differs from Salmenhaara's, which stresses the self-reflexivity of the transformation process. Hepokoski emphasizes more the syntagmatic nature of music, whereas Salmenhaara adheres to the paradigmatic one. From a biosemiotic perspective, we can consider the telos of a symphony to be the same as its Ich-Ton, which is revealed only at the end. On this view, Sibelius' symphonies constitute symbolic portrayals of his "wonderful ego". 


\section{Organic narrativity}

The present study would not be complete with our relating the organic principle to an important species of musical semiosis: narrativity. Narratologists succeeded in demonstrating that very different texts texts extremely varied as to their material and to their external shapes - can be based on just a few narrative categories. Here we speak of the narrativity of a symphony on the level of form, not of aesthetic style. If Richard Strauss' Alpine Symphony and Heldenleben are narrative on the level of verbal reception, in Sibelius narrativity should be understood in a deeper sense, as a property of dynamic formal processes.

If music is organic, can it also be narrative? Is narrativity like language, rhetoric, grammar and other categories that separate the listener from the world of musical gestalts? Not at all - insofar as narrativity is understood in a broader sense, as conceptualized in Greimas' school. Narrativity is a way of shaping the world in its temporal, spatial, and actorial course. Does "organic" narrativity thus mean that the text is articulated according to some primal narration? That it is a story of man's conjunction with or disjunction from nature and cosmos? Narrativity covers many of the sign processes discussed above. Further, one might assume that, in certain forms, it is precisely the way in which man's Dasein imitates the cosmic principles of nature. Narration can of course focus on description and classification of the inner events of Dasein, but it can also be the way in which the world of transcendental ideas is concretized in temporality. As a temporal art, music is thus one of the best means of narrativizing transcendental ideas.

In closing, I return to Sibelius' Fifth Symphony, in order to make a narratological interpretation that relates to the aforementioned ideas of nature, the project of the "modern", and metaphors of organism. My interpretation stems from two listenings during which this narrative program was revealed to me. The first listening occurred at the beginning of the 1960s, probably at a concert given by the Radio Symphony Orchestra in Solemnity Hall of the University of Helsinki, under the direction of Jussi Jalas. Since I was a teenager at that time, my seat was quite near the front of the hall, on the right side, from which one could clearly see the conductor. Nothing remains in my mind from that performance except its climax: the Largamente assai at the end of the finale, the unison orchestral tutti on the note $C$. There 
the dissonance is at its sharpest, and the listener does not at all know where this tragic development might lead - until soon after it the whole symphony cadences and turns toward the tonic E-flat major as its final telos (compared to which the E-flat tonic at the end of the first movement was not a real return to home). At this crucial juncture, on the $\mathrm{C}$ and its leading tone, the conductor raised himself to full height and trembled all over (something Sibelius is also said to have done; see Tawaststjerna 1978: 147). This corporeal sign has remained in my memory.

The second listening was in the summer of 1998 when Esapekka Salonen, visiting conductor of the Marinsky Theater in Mikkeli, including on his program the Fifth Symphony of Sibelius. By then I was already familiar with the piano score, which naturally deepened the experience. At that hearing, the true climax and solution of the work revealed itself as the events in score letter $\mathrm{N}$, Un pochettino largamento, the E-flat minor section. The melody of that section is the first full theme-actor in the entire symphony, which is articulated in the manner of a lied, in periodic form and with a "normal" cadence. This theme is thus experienced as representing a kind of human subject that shows itself against the backdrop of "cosmic" views. As noted earlier, Sibelius' music often gives the impression of a landscape without any human protagonist. Here the subject enters the stage, and it is the suffering, sentimental subject of Schiller (1978), a subject disjuncted from its object and given to resignation. It is a Tchaikovskian, resigned self, whose story has come to an end and whose speech is finally cut off (N: 16), as if by the dysphoric weight of its emotion. It is a subject who is detached from the cosmos, and yet it is basically the same subject which we heard as early as in the previous movement, where it hovered restlessly, not knowing its fate. Tawaststjerna reduces it to another important theme grouping of the Fifth Symphony, the step-motive, which was one of the very first ideas in the work. Certainly these motives were earlier fragments of a subject, but here in the Un pochettino largamento section the subject steps into the foreground as a complete person who has suffered a catastrophe. At the end of the theme, the E-flat minor turns into major, which is like a deus ex machina solution to the threat of impending tragedy. The subject is rescued, so to speak, by being shifted to another cosmic level of nature. The latter is represented by the wellknown swing-motive, which according to Tawaststjerna belongs to the other central motivic group of the symphony. The association of this motive with nature is obvious already from the viewpoint of poiesis, 
as evidenced by Sibelius' diaries, in which he mentions swans in reference to this theme.

This theme thus symbolizes nature and cosmos for the whole symphony. But just when we have reached it, as a safe haven and salvation of the individual from tragedy, even this level falls into a crisis. The swing-theme is led into deeper and deeper dissonance via modulations that move still further away from the tonic. The themeactor whose fate we were following was thus not safe, as we had thought. What is now involved is nature's crisis, Sibelius' Götterdämmerung. The crisis culminates in the above-mentioned $\mathrm{C}$, after which the music leads to a cadence on the tonic of E-flat major with many ensuing chromatic tones - an answer to the gap opened by the "bucolic" motive of the first movement. Therefore the answer which has been kept secret is finally revealed in full light. Perhaps representing a kind of rescue on the cosmic level, it is impossible describe this moment verbally. In any case, there remains yet one more surprise: six sforzando chords punctuate the ending, played by tutti orchestra. These resume the problem of the horn signal and its solution, but the effect is very surprising, lightening, consciously alienating - all is only play; we can sigh in relief.

Yet this description holds true only for the final version of the symphony. In the earlier version, from 1915, the subject-theme appears to the very end as detached, disjuncted from the cosmos, as an individual and alienated theme-actor who does not unite with the cosmic order. As a symbol of the modernist project, it constantly evokes it existence by means of dissonances. Its relation to the ambiguous Neapolitan motive is quite clear as early as in section D of the Finale, when the swing-theme bursts out and the subject-theme is heard as a savage, illogical, and dissonant counterpart, such as one hears in the riotous simultaneities of Charles Ives. There the subjecttheme obviously belongs to the same family as the descending and ascending leaps of fourths in the Neapolitan motive in the first movement (see B: 5-6). The impression is even one of bitonality, and was noticed at the first performance of the work. Otto Kotilainen spoke of a "strange, piercing signal which [...] gives an upsetting impression" (Tawaststjerna 1978: 141). The effect is completely modernistic, and it also represents, in the philosophical sense, the subject of the project of the "modern", which is alienated by its separation from the cosmos.

The gradual unfolding of the subject-theme in its various "rotations" is indeed one of the most characteristic events of the whole 
symphony. It is the central narrative moment. In the 1915 version, the theme never seems to find its proper isotopy, its own Umwelt. It difference remains until the end, when it returns in the Un pochettino largamente, and even there it is still the tragic and isolated theme actor, who is destined for destruction. But in the Un pochettino largamente section it takes on an extremely appealing sensual shape, as if a last gesture is made to serve as the counterpart of the swing-theme. This is related to the idea of the return to the cosmos. In the 1915 version, this subject-theme does not merge with nature in the end, as it does in the final version of symphony. It remains as the pedal point of the strings, to remind one of its existence - even the six chords at the end are heard against this pedal. In the philosophical-semiotic sense, the 1915 version keeps to the modernist project in its narrative program. The separation of the subject from cosmos holds to the very end. By contrast, in the version of 1919 the subject fuses with the cosmic level. Thus, even in the narrative sense, this symphony represents the "organic" in music.

\section{References}

Asafiev, Boris 1977. Musical Form as a Process. Vol. 2. Trans. and commentary by Tull, J. R. (Dissertation at the Ohio State University.) Ann Arbor: University Microfilms International.

Dahlhaus, Carl (ed.) 1985. Die Musik des 18. Jahrhunderts: Neues Handbuch der Musikwissenschaft, Band 5. Regensburg: Laaber Verlag.

Furtwängler, Wilhelm 1951. Keskusteluja musiikista. Mäkinen, Timo (ed.). Porvoo: WSOY.

Hatten, Robert S. 1994. Musical Meaning in Beethoven: Markedness, Correlation, and Interpretation. Bloomington: Indiana University Press.

Hepokoski, James 1993. Sibelius: Symphony No. 5. Cambridge: Cambridge University Press.

Kokkonen, Joonas 1992. Ihminen ja musiikki: Valittuja kirjoituksia, esitelmiä, puheita ja arvosteluja. Jyväskylä: Gaudeamus.

Kostka, Stefan 1999. Materials and Techniques of Twentieth-Century Music. 2nd ed. New Jersey: Prentice Hall.

LaRue, Jan 1970. Guidelines for Style Analysis. New York: Norton.

Lidov, David 1980. Musical Structure and Musical Significance. (Working paper, Toronto Semiotic Circle.) Toronto: Victoria University.

Luyken, Lorenz 1995. “... aus dem Nichtigen eine Welt schaffen...”: Studien zur Dramaturgie im symphonischen Spätwerk von Jean Sibelius. (Kölner Beiträge zur Musikforschung.) Kassel: Gustav Bosse Verlag. 
Mâche, François-Bernard 1983. Musique, mythe, nature ou les dauphins d'Arion. Paris: Klincksieck.

Meyer, Leonard B. 1978. Explaining Music: Essays and Explorations. Chicago: University of Chicago Press.

Mirka, Danuta 1997. The Sonoristic Structuralism of Krzysztof Penderecki. Katowice: Music Academy of Katowice.

Murtomäki, Veijo 1993. Symphonic Unity: The Development of Formal Thinking in the Symphonies of Sibelius. (Studia Musicologica Universitatis Helsingiensis.) Helsinki: Department of Musicology, University of Helsinki.

Peirce, Charles S. 1955. Philosophical Writings of Peirce. Buchler, Julius (ed.). New York: Dover.

Salmenhaara, Erkki 1970. Tapiola. Sinfoninen runo Tapiola Sibeliuksen myöhäistyylin edustajana. (Acta Musicologica Fennica 4.) Helsinki: Suomen Musiikkitieteellinen Seura.

Schiller, Friedrich 1978 [1795]. Über naive und sentimentalische Dichtung. Stuttgart: Reclam.

Tarasti, Eero 1994. A Theory of Musical Semiotics. Bloomington: Indiana University Press.

Tawaststjerna, Erik 1978. Jean Sibelius 4. Helsinki: Otava.

Taylor, Charles 1989. Sources of the Self: The Making of the Modern Identity. Cambridge: Harvard University Press.

Uexküll, Jakob von 1940. Bedeutungslehre. Leipzig: Barth.

\section{Метафоры природы и органицизм в эпистемологии музыки: "биосемиотическое” введение в анализ симфонической мысли Яна Сибелиуса}

Метафоры природы и организма играют центральную роль в западной культуре и искусстве. Весь проект "современности" означает отделение человека от космоса и его законов. Знаки и символы являются арбитрарными и конвенциональными социальными конструкциями. Тем не менее, имеется и много возвращений к иконической имитации природы и биологических принципов - даже в таком виде эзотерического искусства как музыка. Одной из высших эстетических категорий западного музыкального искусства является так наз. "органический рост", который частично наблюдается в симфонии. Понятия "органическое/ неорганическое" использовали как аналитические термины при сравнении творчества Яна Сибелиуса и Густава Малера. Музыку называют "органической", если 1) ее тематические акторы пребывают в подходящем Umwelt (или изотопии); 2) весь музыкальный матерьял восходит к одной основе (т.е. является внутренне иконичным); 3 ) все музыкальные события когерентно следуют один за другим (внутренняя индексальность или принцип роста); 4) музыка стремится к некоей цели 
(темпоральность). Так и идея Юкскюлля о частном Я-тоне (Ich-Ton) любого организма возвращается к нам в музыке. Итак, мы можем сказать, что каздое музыкальное произведение является будто бы "организмом", Я-тон которого определяется воспринимаемыми знаками и тем, как он соотносится со своим собственными музыкальными окружением и формируется другими музыкальными прозведениями.

\section{Looduse metafoorid ja organitsism muusika epistemoloogias: "biosemiootiline" sissejuhatus Jean Sibeliuse sümfoonilise mõtte analüüsi}

Looduse metafoorid ja organitsism on kesksel kohal läänemaises kunstis ja kultuuris. Kogu "modernsuse" projekt tähendab inimese eristumist kosmosest ja selle seadustest. Kuigi märgid ja sümbolid on arbitraarsed ja konventsionaalsed sotsiaalsed konstruktsioonid, pöördutakse siiski sageli looduse ja bioloogiliste printsiipide ikoonilise imitatsiooni juurde, ka sellises esoteerilises kunstiliigis nagu muusika. Üheks tähtsamaks esteetiliseks kategooriaks õhtumaises muusikakunstis on nn. "orgaaniline kasv", mida võib tihti täheldada sümfooniates. Mõisteid "orgaaniline/mitteorgaaniline" saab kasutada analüütiliste terminitena Jean Sibeliuse ja Gustav Mahleri loomingu võrdlemisel. Muusikat nimetatakse "orgaaniliseks", kui (1) tema temaatilised aktorid elavad neile sobivas omailmas (või isotoopias); (2) kogu muusikaline materjal on pärit ühest allikast (st on seesmiselt ikooniline); (3) kõik muusikalised sündmused järgnevad koherentselt teineteisele (sisemine indeksiaalsus või kasvu printsiip); (4) muusika püüdleb teatud eesmärgi poole (temporaalsus). Nii tuleb ka Uexkülli idee iga organismi privaatsest mina-toonist meile muusikas tagasi. Niisiis võime väita, et iga muusikateos on kui "organism" oma mina-tooniga, mis määrab, milliseid märke ta vastu võtab, ja kuidas ta toimib nii omaenda muusikalises ümbruses kui teiste muusikateoste poolt loodud keskkonnas. 